\title{
Genetic variability and performance of Asian swamp eel Monopterus albus (Zuiew, 1793) from West Java cultured in saline water medium
}

\author{
Keragaman genetik dan keragaan belut sawah Monopterus albus \\ (Zuiew, 1793) asal Jawa Barat yang dibudidaya dalam air bersalinitas
}

\author{
Dinar Tri Soelistyowati ${ }^{1 *}$, Ahmad Fahrul Syarif ${ }^{2,}$ Ridwan Affandi $^{3}$, Dendi Hidayatullah ${ }^{1}$ \\ ${ }^{1}$ Departemen Budidaya Perairan, Fakultas Perikanan dan Ilmu Kelautan \\ Institut Pertanian Bogor, Bogor 16680 \\ ${ }^{2}$ Jurusan Budidaya Perairan, Fakultas Pertanian Perikanan dan Biologi, Universitas Bangka Belitung \\ Jalan Kampus Peradaban, Kampus Terpadu UBB Balunijuk, Merawang \\ ${ }^{3}$ Departemen Manajemen Sumberdaya Perairan, Fakultas Perikanan dan Ilmu Kelautan \\ Institut Pertanian Bogor, Bogor 16680 \\ *E-mail: sdinarts@yahoo.com
}

\begin{abstract}
Asian swamp eel Monopterus albus (Zuiew, 1793) is freshwater fish species which is prospective for domestic and export markets. The production is limited depend on the catches of natural population. The cultivation of eel has been carried out to increase the production for sustainability. This study was conducted to evaluate the genetic variability and performance of Asian swamp eel from West Java and its potential cultivation in water based media with salinity. Three populations from West Java were collected of different altitudes from Sukabumi (673 $\mathrm{m}$ asl), Cianjur (429 m asl), Karawang (51 m asl) sized 19-26.5 cm and weighed 4.95-11.4 g. The cultivation was performed during 30 days in water media without substrate at salinity $6 \mathrm{~g} / \mathrm{L}$ with density of $1 \mathrm{~kg} / \mathrm{m}^{2}$ and maintenance at container $50 \times 30 \times 30 \mathrm{~cm}$ completed with shelter pipe of $3 / 4$ inches diameter and $20 \mathrm{~cm}$ length, height of water $10 \mathrm{~cm}$ and water exchange $100 \%$ every day, fed at satiation using Tubificidae once a day. Genetically, all of the populations showed low heterozygosity at 1.19-1.23\% and genetic distance 0.01-0.04. Asian swamp eel adapted better at water salinity $6 \mathrm{~g} / \mathrm{L}$ which indicated by low mesure of osmotic gradient and blood glucose. Asian swamp eel from Karawang showed superior at survival rate (90\%) and daily growth rate (1.42/day).
\end{abstract}

Keywords: Asian swamp eel, Monopterus albus, cultivation, genetic variability, salinity

\begin{abstract}
ABSTRAK
Belut sawah Monopterus albus (Zuiew, 1793) merupakan komoditas ikan air tawar potensial di pasar domestik maupun ekspor, namun produksinya masih mengandalkan hasil tangkapan dari alam karena budidaya belum berkembang. Penelitian ini bertujuan untuk mengevaluasi keragaman genetik dan keragaan belut sawah asal Jawa Barat dan potensinya untuk dikembangkan dengan teknik budidaya di air bersalinitas tanpa lumpur. Tiga populasi belut sawah dikoleksi dari lokasi di Jawa Barat dengan ketinggian berbeda yaitu Sukabumi (673 m dpl), Cianjur (429 m dpl), Karawang (51 m dpl). Sumber genetik belut berukuran 19-26,5 cm dan bobot berkisar 4,95-11,4 g dipelihara selama 30 hari dalam media air tanpa substrat bersalinitas $6 \mathrm{~g} / \mathrm{L}$. Wadah pemeliharaan berukuran $50 \times 30 \times 30 \mathrm{~cm}$ dilengkapi shelter pipa paralon diameter 3/4 inci dan panjang $20 \mathrm{~cm}$ serta ketinggian air $10 \mathrm{~cm}$. Padat penebaran ikan $1 \mathrm{~kg} / \mathrm{m}^{2}$ (20 ekor/wadah), serta pergantian air $100 \%$ dilakukan setiap hari dan pemberian pakan berupa Tubificidae secara at satiation satu kali sehari. Secara genetik ketiga populasi menunjukkan tingkat heterosigositas yang rendah yaitu berkisar $0,19-0,23 \%$ dan jarak genetik $0,01-0,04$. Belut sawah menunjukkan respons adaptasi yang baik dalam media air tanpa substrat pada salinitas $6 \mathrm{~g} / \mathrm{L}$ berdasarkan indikator beban osmotik dan kadar glukosa yang rendah. Belut sawah asal Karawang unggul pada laju pertumbuhan harian $(1,42 /$ hari $)$ dan kelangsungan hidup (90\%).
\end{abstract}

Kata kunci: belut sawah Monopterus albus, budidaya, keragaman genetik, salinitas 


\section{INTRODUCTION}

Asian swamp eel Monopterus albus (Zuiew, 1793 ) is a potential freshwater species in domestic and international markets. The distribution areas of Asian swamp eel population include India, China, Japan, Malaysia, Indonesia, Bangladesh, Thailand, and Vietnam. Its habitat is in an area with an elevation range of $0-1,000 \mathrm{~m}$ asl, a temperature range of $25-32{ }^{\circ} \mathrm{C}$ and a $\mathrm{pH}$ range of 5-9, and it also has diverse morphological characterizations. In Indonesia, Asian swamp eel is spread in Java, Sumatra, Sulawesi, Kalimantan, and West Nusa Tenggara. The exports of Asian swamp eel were addressed to China, Hong Kong, Japan, Singapore, Chinese Taipei, Korea, and Thailand (Khanh \& Ngan, 2010).

Asian swamp eel belongs in facultative air breather species that has an additional breathing apparatus in the form of a thin mucus skin on its oral cavity and takes oxygen directly from the air (Iversen, 2013). Asian swamp eel is cannibal, but the culture system with a high stocking density can reduce its cannibalism (Khanh \& Ngan, 2010). A substrate has functions as an infiltration, a nutrient screen and an aeration for the nutrient requirement. Spawning system of Asian swamp eel is polygamy in which a male eel can fertilize several female eels that choose it with a female quantity of 2-3 individuals (Matsumoto et al., 2011).

The production of Asian swamp eel becomes a serious challenge, because the population of eel in nature decreases caused by the large use of pesticides and over exploitation (Lei et al., 2012). According to Nugroho et al. (2012), the aquaculture development based on local species has to be conducted to maintain biodiversity through species conservation on farmer level (on farm conservation) for food security. The intensive culture technique of Asian swamp eel in water medium without mud is prospective to be studied for a sustainable production fulfillment to stop the capture of eels from nature. Domestication and culture process by increasing medium salinity were reported to be able to reduce physiological stress and increased production performance (Karim, 2007; Langkosono, 2007).

The physiological ability of an organism in responding changes in its living environment is influenced by its genetical component (Piferrer $e t$ $a l ., 2012)$. In general a population that has a higher genetic variability shows its ability to respond a better environment in its adaptation process to feed suffieciency, water quality, and disease resistance (Gjedrem, 2010). Domestication process of a species allows an organism to survive, grow, and breed in an artificial environment. Genetic variability of population closely relates to growth performance and economical properties such as survival and feed efficiency. According to Dunham (2004), genetic variability is important for longterm sustainability of a species or population so allowing it to adapt to environmental changes.

Studies about genetic variability of Asian swamp eel has still been little studied (Matsumoto et al., 2010; Li et al., 2013). Moreover, environmental optimalization that supports adaptation process and production performance of Asian swamp eel through environmental engineering with saline water medium has still not widely been studied. This study aimed to evaluate genetic variability and performance of Asian swamp eels from West Java and its adaptation response on the culture in saline water medium without mud.

\section{MATERIALS AND METHODS}

\section{The collecting of experimental animals}

Asian swamp eels from West Java were obtained from three paddy fields with different elevations, including Cianjur, Sukabumi, and Karawang (Table 1). Acclimatization and culture experiment of eels were performed in Experimental Pond Faculty of Fisheries and Marine Science Bogor Agricultural University

\section{Genetic variability analysis}

Genetic variability analysis was performed by observing DNA variability through Random Amplified Polymorphic DNA (RAPD) method (Wei et al., 2006). Genetic variability analysis was done at Laboratory of Research and Development Center of Freshwater Aquaculture (RDCFA) Bogor. The DNA extraction using five individuals from each population was performed using phenolchloroform isoamilalcohol (25:24:1) followed by PCR (Polymerase Chain Reaction) process using three universal primers including OPA-09 primer (5'-GGGTAACGCC-3'), OPC02 primer (5'-GATAGGCGTC-3'), OPC-05 primer (5'-GATGACCGCC-3'). Polymerase chain reaction (PCR) process was started with initial denaturation at a temperature of $97{ }^{\circ} \mathrm{C}$ for $10 \mathrm{~min}$, then followed by 40 subsequent cycles at a temperature of $94^{\circ} \mathrm{C}$ for $1 \mathrm{~min}$, annealing at a temperature of $36^{\circ} \mathrm{C}$ for $1 \mathrm{~min}$, elongation at a 
Table 1. Charateristics of locations for collecting Asian swamp eels from West Java and water quality in Cianjur, Sukabumi, and Karawang

\begin{tabular}{lccc}
\hline \multirow{2}{*}{ Charateristic of location } & \multicolumn{3}{c}{ Population origin } \\
\cline { 2 - 4 } & Cianjur & Sukabumi & Karawang \\
\hline Area elevation (m asl) & 429 & 673 & 51 \\
Temperature $\left({ }^{\circ} \mathrm{C}\right)$ & $24.22-30.94$ & $23.49-24.93$ & $31.59-34.70$ \\
& $(20-31)^{*}$ & $(17-30)^{*}$ & $(22-34)^{*}$ \\
Conductivity (ms/cm) & $0.19-0.32$ & $0.12-0.19$ & $0.00-0.40$ \\
Turbidity $(\mathrm{ntu})$ & $15-104$ & $0-275$ & $0-1000$ \\
TDS $(\mathrm{g} / \mathrm{L})$ & $0.12-0.21$ & $0.08-0.12$ & $0.00-0.26$ \\
DO $(\mathrm{mg} / \mathrm{L})$ & $5.91-13.67$ & $1.41-7.68$ & $4.5-13.55$ \\
$\mathrm{pH}$ & $6.64-7.48$ & $7.44-9.36$ & $7.23-7.79$ \\
Salinity $(\mathrm{g} / \mathrm{L})$ & $0.10-0.20$ & $0.0-0.10$ & $0.0-0.20$ \\
\hline
\end{tabular}

*Source: Meteorological, Climatological, and Geophysical Agency (2015).

temperature of $72^{\circ} \mathrm{C}$ for $1.5 \mathrm{~min}$, final elongation at a temperature of $72^{\circ} \mathrm{C}$ for $5 \mathrm{~min}$, and stabilizing at a temperature of $4{ }^{\circ} \mathrm{C}$ for $3 \mathrm{~min}$. PCR products were electrophoresed using agarose gel $2 \%$.

\section{The culture of Asian swamp eels}

The rearing system of Asian swamp eels was performed in a water with a salinity of 6 $\mathrm{g} / \mathrm{L}$, a height of $10 \mathrm{~cm}$ and without mud filled in opaque plastic containers, blue colored tank $(50 \times 30 \times 30 \mathrm{~cm})$, equipped with shelters in the form of pipe pieces with a length of $20 \mathrm{~cm}$, and a diameter of $3 / 4$ inch. Asian swamp eels sizing $19.0-126.5 \mathrm{~cm}$ with a weight of 4.95-11.4 $\mathrm{g}$ were stocked at a density of $1 \mathrm{~kg} / \mathrm{m}^{2}$ (Khanh \& Ngan, 2010) for each population replicate. The culture acclimatization was conducted for seven days by fasting experimental eels and the subsequent rearing was conducted for 30 days with water replacement conducted every day by replacing $80 \%$ water of total water volume in the medium with a new water. Feed given to experimental eels was silk worm Tubificidae once a day to apparent satiation.

\section{Observations of parameters}

Production performance was observed every ten days including survival, length growth, absolute weight, daily growth rate, and biomass (Goddard, 1996). Blood glucose level and osmotic gradient were measured at the end of the study with GLUCODR ${ }^{\circledR}$ kit dan osmometer according to a method described by Karim (2007). Water quality parameters during the culture of Asian swamp eels in recirculation system in a water with a salinity of $6 \mathrm{~g} / \mathrm{L}$ were on controlled ranges: temperature at $26-28^{\circ} \mathrm{C}, \mathrm{pH}$ at $7-8$, and dissolved oxygen at $6.1-6.5 \mathrm{mg} / \mathrm{L}$.

\section{Statistical analysis}

Genetic polymorphism level and heterozygosity were analyzed using TFPGA (Tools for Population Genetic Analysis) program. Interpopulation genetic relationship was analyzed based on genetic distance and dendrogram using UPGMA (unweighted pair group method with arithmetic mean). Production performance was analyzed through analysis of variance at a confidence level of $95 \%$ and was further analyzed through Duncan's test, while osmotic rate and blood glucose level were analyzed through descriptive statistic.

\section{RESULTS AND DISCUSSION}

\section{Genetic variability}

The result of the amplification of DNA samples of Asian swamp eels from Sukabumi, Cianjur and Karawang using three primers including OPA09 primer, OPC-02 primer and OPC-05 primer is presented in Figure 1. Fragments sized 3003000 bp with a fragment number range of 9-14 (Cianjur), 9-13 (Karawang), and the lowest was 6-12 (Sukabumi).

Genetic variability level of Asian swamp eels from West Java ranged 76.19-83.33\% with a heterozygosity of $0.1947-0.2372$ (Table 2). Asian swamp eel populations from West Java were thought to be geographically isolated but their reproduction rates were not limited in the 

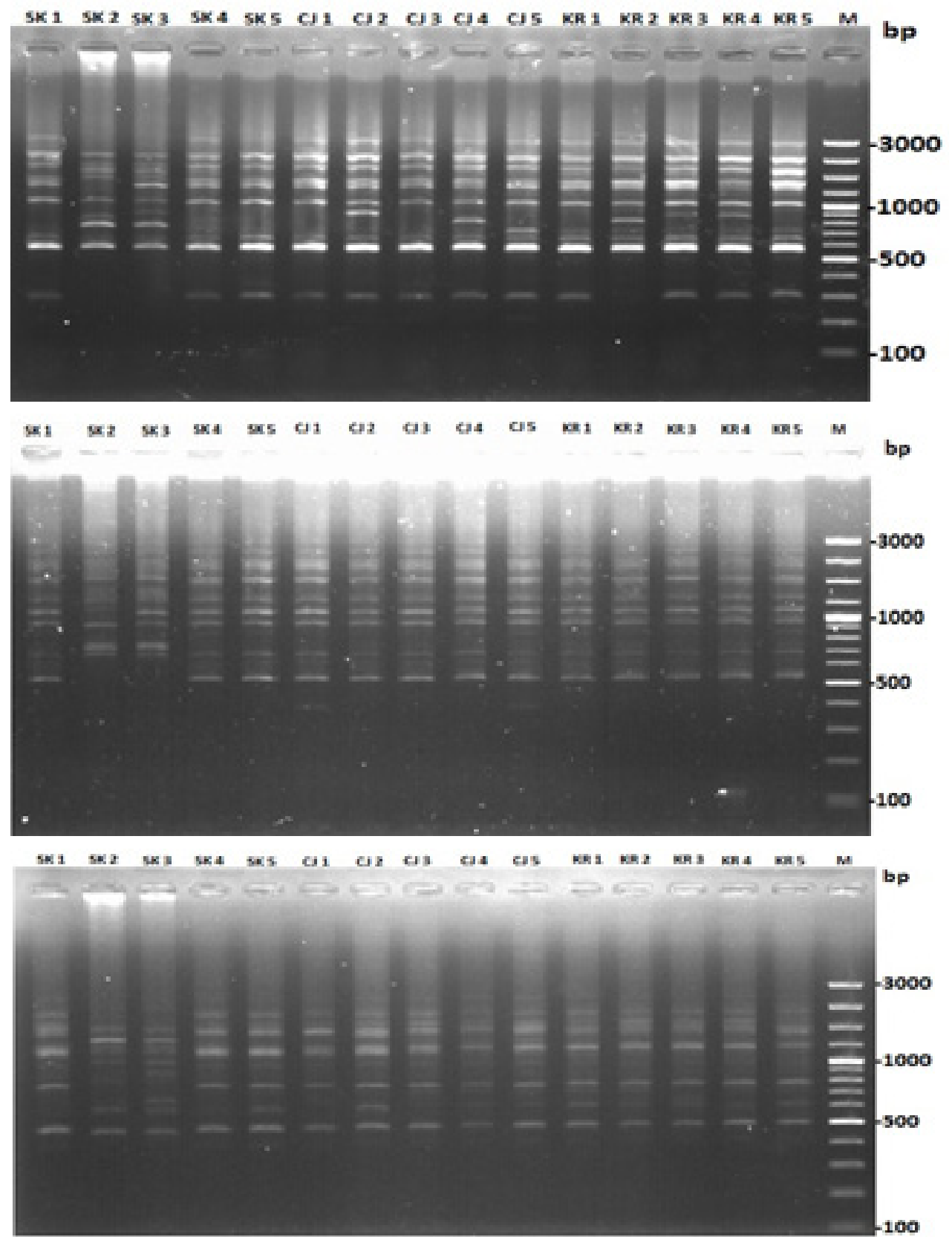

Figure 1. The amplification of Asian swamp eel DNA using OPA-09 primer, OPC-02 primer, OPC-05 primer. Note: SK 1-5 = Sukabumi population, CJ 1-5 = Cianjur population, KR 1-5 = Karawang population, and marker leader (M).

populations so their heterozygosity was low but their genetic variability was high. Populations that are isolated and are limited in genetic source for the continuity of generations allow to experience gene washout, but their genetic variabilities provide success chances to adapt to environmental changes to survive in a long-term period (Wei et al., 2006).

Asian swamp eels from Cianjur, Karawang, and Sukabumi showed a close relationship with a genetic variability difference of $2-5 \%$. Genetic variability difference can increase genetic distance among populations influenced by conditions of native habitats of Asian swamp eel populations (Kusmini et al., 2011; Lorenzen et al., 2012). According to Setijaningsih et al. (2007), the high or the low value of similarity index is influenced by forming genetic resources, the higher the similarity index indicates an exclusivity or suspected to be a closed population.

Performance of Asian swamp eels in the culture system without any substrate

The adaptation response of Asian swamp eels to the culture system without any substrate with a salinity of $6 \mathrm{~g} / \mathrm{L}$ demonstrated a decrease pattern 
on osmotic load to the water medium compared to a salinity of $0 \mathrm{~g} / \mathrm{L}$ (Figure 3). Osmotic rate of Asian swamp eel from Karawang was the lowest in the water with and without salinity compared to eels from Cianjur and Sukabumi. High osmotic rate in the rearing system without any substrate with a salinity of $0 \mathrm{~g} / \mathrm{L}$ causes an organism becoming stress so required an energy to overcome stress through the breakdown of glucose in the blood. Stress is a physiological response to maintain homeostasis through cellular metabolism regulation causing a decrease of blood volume, liver glycogen reserves, and the increasing of blood glucose (Affandi \& Tang, 2000).

In general blood glucose decreased starting from week-2 of the rearing period (Figure 4).
The decreasing trend of blood glucose levels on those three Asian swamp eel populations was a good adaptation response indicator to stress in the culture system without any substrate. In the population of eels from Sukabumi blood glucose level increased on week two then decreasing on week three. A failure in responding unusual environmental conditions could cause eels becoming stress so required an energy to maintain homeostasis through cellular metabolism regulation that causes a decrease in liver glycogen and an increase in blood glucose (Hadiroseyani et al., 2016). According to Porchase et al. (2009) stress is an adaptation to physiological changes which was resulted from various environmental stressors.

Table 2. Genetic variability based on the number and the size of amplified DNA fragments from three Asian swamp eel populations from West Java

\begin{tabular}{ccccc}
\hline Population origin & $\begin{array}{c}\text { The number of } \\
\text { DNA fragments }\end{array}$ & $\begin{array}{c}\text { The size of DNA } \\
\text { fragments (bp) }\end{array}$ & Polymorphism (\%) & Heterozygosity \\
\hline Cianjur & $9-14$ & $300-3,000$ & 83.33 & 0.2291 \\
Sukabumi & $6-12$ & $300-3,000$ & 76.19 & 0.1947 \\
Karawang & $9-13$ & $300-3,000$ & 83.33 & 0.2372 \\
\hline
\end{tabular}

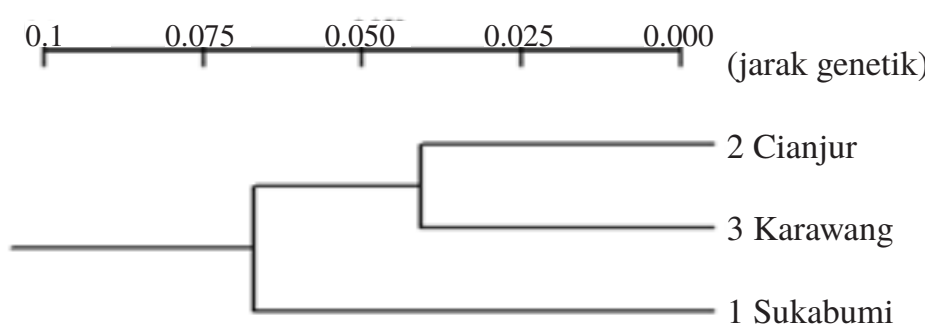

Figure 2. Genetic relationship dendogram of Asian swamp eels from West Java (Cianjur, Sukabumi, and Karawang).

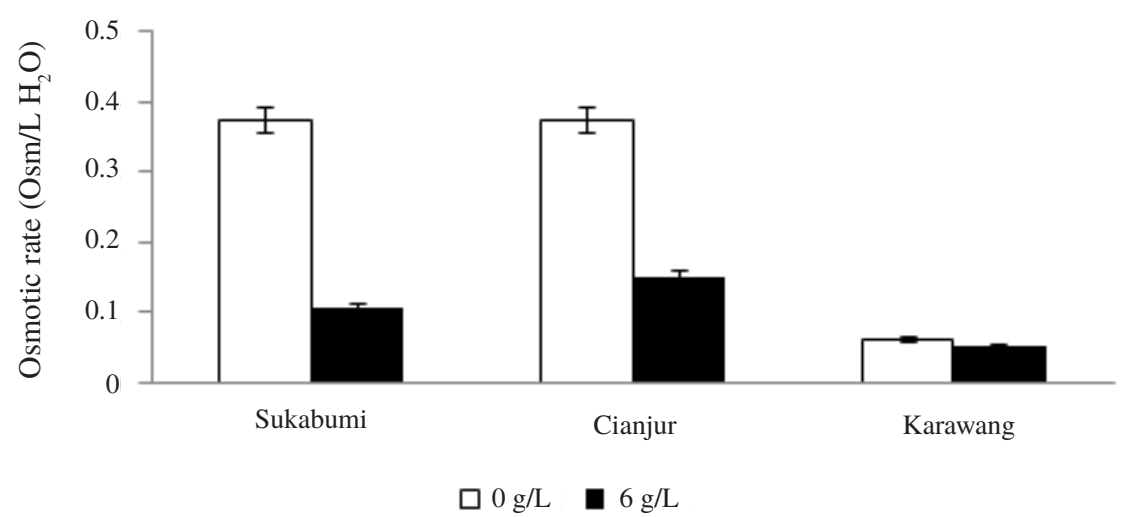

Figure 3. Osmotic rate of Asian swamp eels from Sukabumi, Cianjur, and Karawang with the culture system without any substrate in a water with a salinity of $6 \mathrm{~g} / \mathrm{L}$ after a 30-day-rearing. 
Physiological response of an organism for balancing ion contents in its body fluid with ion contents in the environment influences production phenotype and survival of an organism. Asian swamp eel from Karawang was superior on daily growth rate $(1.42 \%)$ on a 30 -day rearing in a water without any substrate with a salinity of $6 \mathrm{~g} / \mathrm{L}(\mathrm{P}<0.05)$, while the highest biomass was generated in eel from Sukabumi, but its absolute length gain was the lowest, while survivals were not significantly different among those three populations ranging $76.67-90 \%$ (Table 3).

Genetic variability is a key parameter of the fitness of a population that ensures its sustainability and ability to passively respond natural or artificial selection (Lorenzen et al., 2012). Asian swamp eel populations from Sukabumi, Cianjur, and Karawang had genetic variability over $75 \%$ but their heterozygosity was low that was 0.2 (Table 3 ). Genetic variability commonly positively correlates with a success chance to adapt to changes in environmental conditions, but in Asian swamp eel from Sukabumi there was a significant difference in temperature at its habitat $\left(23-24{ }^{\circ} \mathrm{C}\right)$ with the environmental condition in the culture system $\left(26-28^{\circ} \mathrm{C}\right)$.
The high polymorphism level in a population shows the effectiveness of an individual on the reproduction process in its habitat (Kristanto \& Kusrini, 2007; Kusmini et al., 2011). Low genetic variability is thought to relate to limited gene exchange or narrow population size so inbreeding increases and impacts on a slow growth and a low adaptation level. If a genetic potential is supported by an appropriate environment so it will be expressed optimally and will produce maximum phenotype too (Ath-thar et al., 2014). A population with a high genetic variability has a higher surviving chance, because many alternative genes or gene combinations are available to respond changes in encountered environmental conditions (Dunham, 2004).

Li et al. (2013) declared the presence of differences in genetic variability between eels that live in nature and cultured eels. Eels that live in nature have a higher genetic variability compared to cultured eels. Liu et al. (2009) also stated that the genetic variabilities of cultured populations are lower compared to wild populations. The low genetic variability will lead to degradation in ability to adapt to new environments.

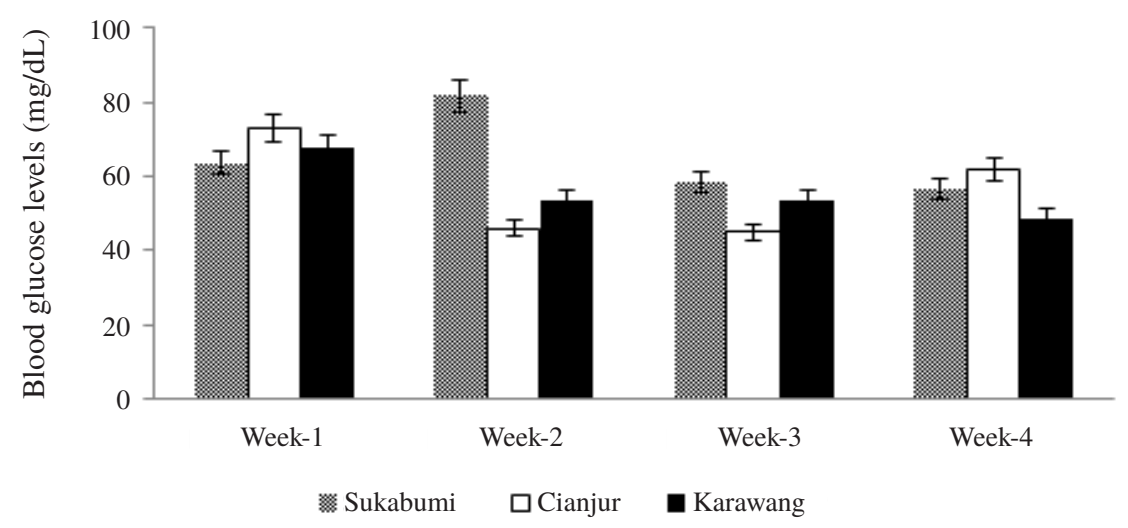

Figure 4. Blood glucose levels of Asian swamp eels from Sukabumi, Cianjur, and Karawang on week 1-4 in the rearing system with the culture system without any substrate and a salinity of $6 \mathrm{~g} / \mathrm{L}$

Table 3. Phenotype performence of Asian swamp eels from Sukabumi, Cianjur, and Karawang population reared for 30 days in the culture system with a water medium without any substrate at a salinity of $6 \mathrm{~g} / \mathrm{L}$

\begin{tabular}{lccc}
\hline \multirow{2}{*}{ Phenotype performance } & \multicolumn{3}{c}{ Population origin } \\
\cline { 2 - 4 } & Cianjur & Sukabumi & Karawang \\
\hline Daily growth rate (\%/day) & $0.69 \pm 0.09 \mathrm{a}$ & $0.58 \pm 0.12 \mathrm{a}$ & $1.42 \pm 0.20 \mathrm{~b}$ \\
Absolute length growth (cm/day) & $1.42 \pm 0.23 \mathrm{~b}$ & $2.31 \pm 0.27 \mathrm{a}$ & $1.88 \pm 0.11 \mathrm{a}$ \\
Survival (\%) & $87.50 \pm 7.50 \mathrm{a}$ & $76.67 \pm 2.89 \mathrm{a}$ & $90.00 \pm 5.00 \mathrm{a}$ \\
Biomass (g) & $27.69 \pm 0.29 \mathrm{~b}$ & $17.74 \pm 0.00 \mathrm{a}$ & $19.43 \pm 7.79 \mathrm{ab}$ \\
\hline
\end{tabular}




\section{CONCLUSION}

Genetic variability level of Asian swamp eels from West Java ranged $76-83 \%$ with a heterozygosity of $0.19-0.23$ and had a genetic distance of 0.01-0.04. The decreasing of osmotic rate and blood glucose of Asian swamp eels cultured in a water medium at a salinity of $6 \mathrm{~g} / \mathrm{L}$ indicated a good adaptation response to stress. Asian swamp eel from Karawang was superior on daily growth rate by resulting a value of $1.42 \% /$ day, an absolute length growth of $1,88 \mathrm{~cm} /$ day, and a survival of $90 \%$.

\section{REFERENCES}

Affandi R, Tang UM. 2002. Fisiologi Hewan Air. Riau: Unri Press.

Ath-thar MF, Soelistyowati DT, Gustiano R. 2014. Reproduction performance of snakeskin gouramy Trichopodus pectoralis Regan 1910 from Sumatera, Jawa and Kalimantan. Jurnal Iktiologi Indonesia 14: 201-210.

[BMKG] Badan Meteorologi, Klimatologi, dan Geofisika. 2015. Prakiraan cuaca Propinsi Jawa Barat. http://www.bmkg.go.id/BMKG_ Pusat/Informasi_Cuaca/Prakiraan_Cuaca/ rakiraan_Cuaca_Propinsi.bmkg?prop=13. [diacu 2015 Agustus 26].

Dunham RA. 2004. Aquaculture and Fisheries Biotechnology: Genetic Approach. Cambridge: CABI Publishing.

Gjedrem T. 2010. The first family-based breeding programs in aquaculture: review. Aquaculture 2: 2-15.

Goddard S. 1996. Feed Management in Intensive Aquaculture. New York (US): Chapman and Hall.

Hadiroseyani Y, Sukenda S, Surawidjaja EH, Utomo NB, Affandi R. 2016. Survival rate of transported ricefield eels Monopterus albus (Synbranchidae), in open and closed system at water salinity level of 0 and $9 \mathrm{~g} / \mathrm{L}$. AACL Bioflux 9: 759-767.

Iversen KN. 2013. Cardiovascular anatomy and cardiac function in the air-breathing swamp eel Monopterus albus. Biochemical Physiology And Molecular Integrated Physiology 164: 171-180.

Iwama GK, Alfonso LOB, Vijayan MM. 2005. The Physiology of Fishes: Stress in Fishes. Evans DH, Claborne pJB, editor. New York: CRC Press.

Karim M. 2007. Pengaruh salinitas dan bobot terhadap konsumsi kepiting bakau Scylla serrata Forsskal. Jurnal Sains dan Teknologi 7: 85-92.

Khanh NH, Ngan HTB. 2010. Current practices of rice field eel Monopterus Albus (Zuiew, 1793) culture in Vietnam. Research institute for Aquaculture 15: 26-29.

Kusmini II, Gustiano R, Mulyasari. 2011. Genetic characterization of kelabau fish Osteochilus kelabau from several locations in West Kalimantan using RAPD (Random Amplified Polymorphism DNA) method. Berita Biologi 10: 449-454.

Kristanto A, Kusrini E. 2007. Peranan faktor lingkungan dalam pemuliaan ikan. Media Akuakultur 2: 183-188.

Lei L, Feng L, Jian TR, Yue GH. 2012. Characterization and multiplex genotyping of novel microsatellites from Asian swamp eel, Monopterus albus. Conservation Genetics Resources 4: 363-365.

Liu YG, Yu ZG, Bao BL, Sun XQ, Shi QL, Liu LX. 2009. Population genetics studies of halfsmooth tongue sole Cynoglossus semilaevis using issr markers. Biochemical Systematics and Ecology 36: 821-827.

Li W, Sun WX, Fan J, Zhang CC. 2013. Genetic diversity of wild and cultured swamp eel Monopterus albus populations from central China revealed by ISSR markers. Biologia 68 : 727-732.

Lorenzen K, Beveridge MCM, Mangel $\mathrm{M}$. 2012. Cultured fish: integrative biology and management of domestication and interactions with wild fish. Biology Review 87: 639-660.

Langkosono. 2007. Budidaya ikan kerapu (Serrenidae) dan kualitas perairan. Neptunus 14: 61-67.

Matsumoto S, Kon T, Yamaguchi M, Takeshima H, Yamazaki Y, Mukai T, Kuriiwa K, Kohda M, Nishida M. 2010. Cryptic diversification of the swamp eel Monopterus albus in East and Southeast Asia, with special reference to the Ryukyuan populations. Ichthyological Research 57: 71-77.

Matsumoto S, Takeyama T, Ohnishi N, Kohda M. 2011. Mating system and size advantage of male mating in the protogynous swamp ell Monopterus albus with parental care. Zoological Science 28: 360-367.

Nugroho E, Sukadi MF, Huwoyon GH. 2012. Beberapa jenis ikan lokal yang potensial untuk budidaya: domestikasi, teknologi pembenihan, dan pengelolaan kesehatan 
lingkungan budidaya. Media Akuakultur 7: 52-57.

Setijaningsih L, Arifin OZ, Gustiano R. 2007. Characterization ofthree strains of giant gouramy Osphronemus gouramy Lac. based on truss morphometries method. Jurnal Iktiologi Indonesia 7: 23-30.

Piferrer F, Ribas L, Díaz N. 2012. Genomic approaches to study genetic and environmental influences on fish sex determination and differentiation. Marine biotechnology 14: 591-604.

Porchase MM, Cordova LRM, Enriquez RR. 2009. Cortisol and glucose reliable indicator of fish. Pan-American Journal of Aquatic Science 4: 157-78

Wei RB, Qiu GF, Song R. 2006. Genetic diversity of rice field eel Monopterus albus in China based on RAPD analysis. Asian Fisheries Science 19: 61-68. 